\title{
Pseudo-translation as a Subset of the Literary System: a Case Study
}

\author{
Maryam Mohammadi Dehcheshmeh \\ University of Ottawa
}

\section{Introduction}

Throughout history, translation has been the foremost method of importing and exporting literary styles among nations. As with any communication tool, however, the act of translation does not occur in a vacuum but rather is embedded in various contextual issues, such as power relations, colonization, cultural development, and globalization, to name a few. That is why people have had various understandings of translation in diverse cultures. The notion of "translation" has gone through many changes, mostly under the influence of the dominant western theoretical understanding within the field. Along with other innovative ideas about translation, pseudo-translation has been one of the concepts emerging out of a new grasp of translation studies in the field. Those new perspectives have led to a drastic shift away from literal, free, and faithful translations to cultural and sociological aspects of translation. As a concept, pseudo-translation has been perceived both negatively and positively, and the boundary between translation and pseudo-translation is somewhat blurred. As Toury (2005) pinpoints, it is a critical process of cultural translation that surpasses the relationships between source and target texts.

Charlie Chaplin's letter to his daughter Geraldine is one example of a pseudo-translation that reflects the socio-political context of its production. In the following discussion, the nature and context of this letter will be examined in light of its character as a pseudotranslation. The study also examines the ideological, economic and status-giving policies of "the undifferentiated patronage outside the literary system" (Lefevere, 1992) which led to the creation of this letter in the form of a pseudo-translation.

The current study examines the definitions of both translation and pseudo-translation and highlights some of the differences between them. An examination of reasons underlying the production of pseudo-translations is then followed by an investigation of examples of contemporary Persian pseudo-translations. Lastly, a case study of the letter itself, including a critical discourse analysis of the text, is offered for consideration. 


\section{What Is Translation?}

In English, the term "translation" derives from the Latin root translatio meaning 'carrying across' (Tymoczko, 2003). Thus translation has been defined as a tool by which the content of text is carried into another language and placed in a target language text. Tytler's principle of translation in 1791, including his quote that "translation should give a complete transcript of the ideas of the original work" (Tytler, 1978, cited in SnellHornby 2006, 61), is an example of this perspective.

Clearly, when we look at the history and theories of translation in various cultures, translation is not considered the same throughout the world. For example, Dilmäj is an old Persian word referring to the act of translation that derives from the Turkish root Dilim Aj meaning "make me speak" (Dehkhoda, 2013).With the vast influence of Arabic in Persia, the word Tarjomeh, with its Arabic root meaning "biography," became popular as a word meaning translation. As Tymoczko (2003) highlights, these different meanings illustrate how the concept of translation, with all its distinct historical associations, has been understood differently. As could be surmised, both the act and norms of translation in non-western cultures are different from western perspectives.

In the 1980s, 'cultural turn' emerged in translation studies with the advent of the Manipulation School and its descriptive, target-oriented, functional, and systemic nature. The founders of this school went beyond the notion of source text, faithfulness, and tertium comparationis. The 'original author' was dethroned, and the 'target text' was situated in the target language culture. As Snell-Hornby (2006) emphasized, what is truly important is not the thoughts and words of the author (the death of the author) but rather the readers and the receiving culture (the birth of the reader).

Within the context of these newer perspectives in translation studies, pseudotranslation, as a subset of the literary system, has been marginal so far.

\section{What Is Pseudo-translation?}

The term 'pseudo-translation' (PT) traces back to 1976 when Anton Popovič introduced 'fictitious translation' to define an original work published as a translation so as to achieve a wider readership. The author would have a specific literary plan that could be 
realized through presenting his/her work as a translation. A fictitious translation is called 'quasi metatext' from the stand point of text theory (Robinson, 1998). Moreover, other terms referring to PT in English include 'disguised translation,' 'pretended translation,' and 'assumed translation' (Okhovat, 2006).

How it is that we have numerous terms referring to the same concept? The most direct response to this question is that these terms don't, in fact, refer to the same concept! Every scholar interprets PT from his/her particular point of view. According to Robinson (1998), for example, a PT is not only an original text that pretends to be a translation but also a translation that is taken to be an original text. He also defines PT as "a work whose status as 'original' or 'derivative' is, for whatever social and textual reason, problematic" (Robinson, 1998, 183). It is not always easy to make a clear-cut distinction between the two because there are differing contexts related to each literary work, as illustrated in the following examples from around the world:

The Living Bible was described by its authors as an English paraphrase of the Bible, representing what Roman Jakobson refers to as an 'intralingual translation.' In the preface, its authors explained that their work was based on the existing English translations of the Bible rather than being a direct English translation of Hebrew, Aramaic, and Greek texts. However, the Living Bible itself is in fact most often read as a translation, meaning a text translated from another language (Robinson, 1998).

In Turkish literature, many poets and writers were strongly influenced by Western works, to the point where directly translating phrases and borrowing images from Western works were a common practice among Turkish writers. One example of such a practice is Ahmed Hamdi Tanpinar's short story entitled Abdullah Efendi'nin Rüyalar [The Dreams of Abdullah Efendi] which was greatly influenced by Gérard de Nerval's Aurélia (Tahir Gürçağlar, 2010).

Many such examples can also be found in Persian literature. Early Iranian translators, such as Mirza Habib Esfahani, Mahmoud Hedayat, and Mohammad Hasan Khan Etemadolsaltaneh, while translating Western works into Persian, not only adapted the names of characters, but also changed the settings and the atmosphere at times. On occasion, they even appropriated the content of the stories and dramas in texts (Okhovat, 2006).Numerous other examples can be found within Persian literature. When 
are such works an example of PT? And in what ways can a PT be distinguished from what we refer to as an adaptation, plagiarism, or imitation?

As Apter points out, "translation reproduces not an original text, but an afterlife cloned from the (lost) life of the original" (2005, p.171). She states that "fiablity" and "fidelity" (two issues of interest for translation ethics), which are vital to the determination of PT, have shifted toward the conditions of textual reproducibility. Following Benjamin, she defines translation in its most scandalous form, "as a technology of literary replication that engineers textual afterlife without recourse to a genetic origin" (Apter, 2005, p.171).

To partly solve the ambiguity which exists in the definition of PT, Tahir Gürçağlar (2010) suggested the term 'concealed translation' which is broad enough to convey diverse textual strategies. Based on her classification, she believes PTs ${ }^{1}$ are a type of purported translated text even as there is no original text for them. It is important to note, however, that concealed translations are even more common than PTs as a marginal translation activity in Turkey; hence, the term 'concealed translation' covers a large variety of textual strategies within Turkish literature.

In a similar vein, Rizzi (2008) stated that the ambiguity results from the dichotomy between translation and PT, and he argued that we should change our understanding of PT in lieu of considering a text as either a translation or a PT. Rizzi concluded that the coexistence of PT and translation within the same text is contingent upon our understanding of translation. His position suggests that the notion of translation may be more variable than what we have previously thought. In terms of PT, the central quest then becomes not to determine whether a particular text is in fact a forgery, but rather to better understand the complicated relationships between translators, clients, and patron/dedicatees. From this perspective, it becomes clear that "the scandal is not the PT ... but the unhistorical dichotomization of translation vs. non-translation" (Rizzi, 2008, p. 161).

${ }^{1}$ In the present paper, PT is the same as PT in Tahir Gürçağlar's classification. 


\section{The Reasons Of Pseudo-translation}

According to Okhovat (2006), who noted that a bibliography of PTs in Persian literature would turn into a bulky book, most Iranian PTs fall within the category of political literature. Even though Iranian PTs are plentiful within literature, they are still a littlestudied example of "cultural dynamics" (Toury, 2005), similar to PTs within other cultures such as Western (Rizzi, 2008) or Turkish texts (Tahir Gürçağlar, 2010). Okhovat argues that it is not easy to decide about the 'genuineness' of translations because, as he puts it, PTs reside in shadow. The authors (or pseudo-translators) are in disguise; therefore, the "genuineness" of their works can only be surmised. One interesting point is that when everything is under a veil such as this, people by and large trust the document, perhaps because they don't have any alternative. As he puts it, readers tend to trust that a publication is 'authentic' whether the author uses a pseudonym or his/her actual name, or whether it is an original or translated work. It is a rare event for a reader to scrutinize a text in order to verify if it is a real translation or if it is a "Huckleberry Finn's trick."

Tahir Gürçağlar (2010) claims that two main reasons for the existence of PTs, at least in Turkey, are commercial advantages and controversial cultural issues, including women's sexuality, anti-capitalism, and abstract art. Likewise, it is necessary to note that although the notions of adaptation, plagiarism, and imitation carry negative connotations given the concepts of authorship and literary ownership, in the past such terms were referred to as 'influence' or 'inspiration,' and they were popular textual strategies among Turkish writers.

A similar situation exists in terms of Iranian literature. Our ancestors, for example, didn't read Samak-e 'ayyār '̉because of its writer Faramarz Khodadad ${ }^{4}$ and Hezār-o yek

\footnotetext{
${ }^{2}$ The phrase refers to a novel entitled Adventures of Huckleberry Finn written by Mark Twain (1884). Okhovat states that not only is "Huckleberry Finn's trick" the name of a syndrome in medical science, but it also it refers to a "pathological" tendency among writers to write under pseudonyms.

${ }^{3} \mathrm{~A}$ prose narrative that stemmed from a professional storytellers' environment and was passed on orally and penned around the $12^{\text {th }}$ century (Encylopaedia Iranica, 2010).

${ }^{4}$ His name has appeared in the text (but wasn't attested in other sources) as the compiler, author, and the narrator of the story (Encylopaedia Iranica, 2010).
} 
shab ${ }^{5}$ because of its translator Abdol latif Tosuji. ${ }^{6}$ Such literature was read because of its interesting stories. Neither the writer nor the translator was of central importance (Okhovat, 2006). Okhovat enumerates three main reasons underlying PTs produced in Iran:

1. When young talented writers cannot find the proper positions they deserve in literary society, they have to publish their works as translations. This is a prevalent practice in a society like Iran where foreign works are more 'prestigious' and 'worthwhile' in readers' view. Apart from a few noted writers, the rest cannot vie with their foreign counterparts. Sometimes, whether the name of the author or translator is mentioned or not doesn't matter, the only thing that matters is this clause at the end of the work 'translated from a foreign source.' Then, when it is perused precisely, the local atmosphere of the work shows itself clearly! Okhovat bemoans that there are some medical articles in newspapers that are truly the translations of foreign texts but whose content is, in fact, similar to the average medical knowledge of Iranian physicians themselves. The only reason to justify why they have translated such articles is that foreign specialists are more appealing!

Tahir Gürçağlar (2010) claims that when compared to the original Turkish work, translated texts create commercial advantages for publishers because of increased sales. Commercial advantages of translated works for the publishers have also been noted to be an important factor in Persian literature.

2. The controversial and political nature of some subject matter encourages authors to write under the name of a translator in order to avoid either potential or actual harm to themselves. The patronage of the time sometimes obliges writers to submit to self-censorship, to use ironies, allusions, and

\footnotetext{
${ }^{5} \mathrm{~A}$ widely-known collection of tales called Arabian Nights in English. It was originally translated from Persian, Sanskrit, and Greek, including a book entitled Hazār afsāna (a thousand tales), whose physical evidence disappeared long ago. It is a story of a misogynist king who took a virgin bride each night and beheaded her on the morrow. A thousand tales began to be narrated when his vizier's daughter Šìāzād and her maid Dīnāzād entered the story (Encylopaedia Iranica, 2010).

${ }^{6}$ He translated Arabian Nights into Persian in mid-19 ${ }^{\text {th }}$ century.
} 
other creative strategies and to conceal their works under the veil of translation.

3. Because the general public tends to criticize translations less severely than they do original written works, some writers will publish their works behind the mask of a translator. Thus, writers who raise new, challenging, or contentious theoretical issues may do so more safely under the guise of a translated work.

\section{Pseudo-translations in Iran}

Perhaps due to the social and political circumstances in Iran, few studies address PTs within Persian literature. Thus it is valuable to embark on an initial exploration of this area.

In the early months of 1824, a man named James Justinian Morier published a novel entitled The Adventures of Hajji Baba of Ispahan about the relatively hermetic Iranian society of Qajar-era. The main character of the novel was Hajji Baba who had journeyed from Central Iran to Armenia, Turkmenistan, Baghdad, and then Istanbul. Morier characterized him as a "rogue"7 to develop the narrative in the way that he desired. Morier was an English private secretary of Harford Jones, who was dispatched as the special envoy of King George to the Qajar Fath Ali Shah (Rastegar, 2007). According to Okhovat (2006), Morier pretended that his novel was a translation of Hajji Baba's journal in order to protect his work from accusations that it was biased due to Western ideology. He concealed himself as Hajji Baba because he wanted to describe Iranian society through the 'oriental' eyes of Persians themselves. His novel was later translated by Mirza Habib Esfahani ${ }^{8}$ in the $20^{\text {th }}$ century.

In a similar vein, a book entitled Baggasht Be Nakoja-Äbäd [Returning to theIdyllic Place] came out in the spring of 1978, and it included the dialogues between Simone La Marte

\footnotetext{
${ }^{7} \mathrm{~A}$ term used by British reviewers to describe Hajji Baba (Rastegar, 2007).

${ }^{8}$ He made a free and highly fluent translation of the text and gave a local color to all foreign cultural aspects. For a while, some literary scholars thought that his text was the original and Morier's the translation of it!

${ }^{9}$ Published by Ehya Publishing Co., Tabriz, Iran
} 
and Emanuel Artery, ${ }^{10}$ along with a critique of them (translated by Ali Kabiri which is apparently a pseudonym as well). Due to the political zeitgeist at the time of publishing, the pseudo-translator attempted to express his/her idea regarding the necessity of violence against the Pahlavi regime while also refuting the 'struggle for existence' theory without mentioning either of these directly. Accordingly, the pseudo-translator formulated a setting in Latin America with numerous foreign names and claimed that s/he has translated a work which addresses third world issues and Latin American society (Okhovat, 2006).

Don Kishothayye AsrehMä ${ }^{-11}$ [Don Quixotes of Our Era] is another example, published in 1976, that includes four articles (published previously in Jahäneh No and Fasleh Sabz) by four different bogus writers created by their pseudo-translator. ${ }^{12}$ Similar to the previous example, it had an opposing political ideology expressed behind the mask of imaginary writers (Okhovat, 2006).

\section{Charlie Chaplin's Letter}

Charlie Chaplin's letter to his daughter Geraldine is a well-known piece of writing that is recited in many Iranian assemblies as an invaluable example of how to care for people who are less fortunate and how to live an honorable life. The letter has been highly regarded by many people, both before and after the Iranian Revolution. More recently, some Iranian official media outlets have even referenced it to promote the hijab by citing Chaplin's opposition to female nudity. Attention was thus heightened when a recent interview was circulated on the Internet with a person called Farajollah Saba claiming to be the author of this famous letter. This disclosure has caused astonishment in the minds of many who have always believed the letter to be a direct translation of Chaplin's

\footnotetext{
${ }^{10}$ Because these are not real characters, the spelling of their names is uncertain. There is no account of who these people are, how their dialogues have been compiled, etc.

11 Published by Haghighat Publishing Co.

${ }^{12}$ Again, the translator is Ali Kabiri and the writers are Thomus Burger et al., as it has been found via an online search.
} 
original text. ${ }^{13}$ Saba, an experienced journalist, stated that he originally wrote the letter in Rošanfekr Journal ${ }^{14}$ more than 30 years ago, prior to the Islamic Revolution in Iran.

An extensive examination of various libraries and websites, in addition to the many English books that have been written about Chaplin's life, fails to bring to light an English original text for the letter in question. It is interesting to note that several books have been published in Persian regarding this letter, such as Ravānšenäsie nämeye Charlie Chaplin be doktaras Geraldin [the psychology of Charlie Chaplin's letter to his daughter Geraldine], ${ }^{15}$ and Nämehaye Charlie Chapline be doktaraš: Saršär az noktehāye hošdār dahandeh be ensān omuman va be doktarän va zanänkosusan dar bäbe zendegi va zistane šeräfatmandäneh [Charlie Chaplin's letters to her daughter: full of warning points generally to human beings and particularly to women about living with honor. ${ }^{16}$

\section{a. Charlie Chaplin In Iran}

The high popularity in Iranian society of an Anglo-American like Charlie Chaplin may appear peculiar to some. Apart from his remarkable success in acting and filmmaking, there are undoubtedly some other reasons for his notable reputation, which can be studied from various vantage points, such as his movies, his personal life, historical and political changes in the West (represented in his movies) concurrent with those in Iran, and the like. Looking briefly through some of those perspectives offers some illumination.

Chaplin has always been venerated both before and after Islamic Revolution as a paragon who, despite all hardships in childhood, achieved lofty heights in his career. In most of his movies, he played the role of a vagrant "tramp" with the dignified and noble manners of a gentleman, although he belonged to a lower social caste. More often than

\footnotetext{
${ }^{13}$ An interview with Farajollah Saba was published in SeratNewson May 23 ${ }^{\text {rd }}$ of 2012. Then, the interview was widely circulated in different websites, weblogs, social networks, etc. The translation of some relevant parts of the interview is available in Appendix III.

${ }^{14}$ A weekly journal founded by Raḥmat Moșțafavi in 1953 (Encyclopaedia Iranica, 2010).

15 Written by Morteza Omid khah and Maryam Rahimimand, published by Niloufaraneh Publishing Co. in 2006.

${ }^{16}$ Written by David Robinson (who doesn't have a book with this title!) and translated by Mahshid Zarif, published by Seraj Andishe Publishing Co., in 2012.
} 
not, the target of criticism in those movies was aristocrats who in the plots were immersed in the mundane world and forgot how to show altruism and mercy upon the destitute. As could be expected, in people's minds, the tramp became a hero whose decisions and deeds were flawless. On the other hand, he was also at some points portrayed as a person who had a traditional middle-class lifestyle, and this portrayal catered to the leftist stereotypes against capitalism. In Iranian society, similar ideologies were gaining momentum among people before the Islamic Revolution-another possible reason for Chaplin's fame.

In present-day Iran, Chaplin is still revered by people and the media at large. A multifunction movie theater-used for different film festivals, including Fajr Film Festival, the most important one-is named after Chaplin. Although it is rare for an AngloAmerican to be praised by Iranian government media, a famous song in Chaplin's honour called "The Clown" ${ }^{17}$ has been shown frequently on Iranian State TV.

\section{b. The Socio-political Zeitgeist At The Time The Letter Was Published}

After the coup d'état in 1953 during which Mohammad Mosadegh, the prime minister, was removed from his position, the control of the media by the monarchy increased significantly. The Organization of Intelligence and National Security, (known as SAVAK), founded in 1957, became responsible for controlling cultural and political ideology and identifying opposition groups. SAVAK set up an investigation bureau in the Ministry of Culture and Art so as to supervise and monitor the publication of books and newspapers. As a result of these repressive activities, the number of Iranian books and newspapers that were published decreased drastically by the late 1960s (Roshan, 2011). Writers, translators, and academics alike encountered an identical attitude on the part of the media, the authorities, and the educational establishments, all of whom followed the policies of the totalitarian ruler.

Mohammad-Reza Shah ${ }^{18}$ adopted a repressive policy regarding any and all opposition to his regime. As one could imagine, this led to various reactions by the Iranian people,

${ }^{17}$ Sung by Mohammad Esfahani. The video shows Chaplin in some of his movies, and the lyrics acclaim the clowns' attempt to make people laugh while deep down they may be sad.

${ }^{18}$ The last king of Pahlavi Dynasty (1941-1979). 
from passivity to violent confrontations with the authorities, as Milani (1994) has outlined. Activists, including nationalists, Marxists, and Islamists, arose within diverse organizations, and they represented a whole Iranian generation, both at home and abroad. The Iranian struggle against the Pahlavi regime resulted in the Islamic Revolution, led by Ayatollah Khomeini who had announced his disagreement with the Shah's White Revolution in 1963. The white revolution caused dramatic changes in “...electoral reform (including women's suffrage), literacy corps, health corps, rural development corps, village tribunals or "House of Justice", ...educational reform, and the religious corps" (Aryanpur, 1973, 289-290). According to Milani again, “in Iran's political culture, religion seems inseparable from politics" (1994, 90). As a popular religious leader, Ayatollah Khomeini promised people increased prosperity and the eradication of moral corruption resulting from the westernization of their culture. His slogans were highly attractive at the time because people, many of whom lived in poverty, desired such things as increasing welfare and rooting out moral corruption.

\section{c. Epitext And Peritext}

In an interesting study, Rizzi (2008) attempted to test a working definition of "translation" by investigating its bifurcated aspects, including 1) peritexts, such as prefaces, blurbs, table of contents and 2) epitexts, comprising all referential documents separate from the text itself, such as letters, reviews, and relevant archival texts. According to the working definition, if both peritext and epitext corroborate the 'translationness' of the text, then it is a translation proper. However, if the peritext indicates that it is a translation but the epitext specifies it is a PT, there are two possibilities. The first possibility occurs if the epitexts, claiming the PTness, have been written long after the text itself. When this occurs then the text is still considered a translation by the cultural system that has produced it. This holds true even if the epitexts' culture is not in accord. A second possibility occurs when the epitexts are produced by the culture that has also created the text. In this latter case, it becomes a clear case of a PT.

Following Rizzi's bifurcated definition, the present study utilizes these two categories in its analysis of Charlie Chaplin's letter to his daughter. The original text was published as a journal article and contained no further explanation. No text exists that could be considered a peritext per se. 
In terms of the epitexts, the first writing on the subject of the PTness of the letter was published in 2012 (based on the present author's research). After that, websites such as SeratNews, ${ }^{19}$ AftabNews, ${ }^{20}$ Kalameh, ${ }^{21}$ and FarsNews, ${ }^{22}$ along with various social networks and some weblogs, discussed the PTness of the text and posted an interview with Saba describing the story behind the creation of the letter.

During this time, the Iranian official media continued to present the text as the translation of a letter originally written by Charlie Chaplin himself. This indicates the first sub-scenario above-mentioned by Rizzi applies here.

\section{d. What Makes Charlie Chaplin's Letter An Example of Pseudo-translation?}

The letter writer used deft strategies to make the letter in question appear to be a translation of an original text; however, translations and original texts bear some differences that he couldn't escape from. Herewith, some of these differences, adapted from the criteria Okhovat (2006) has used to study his cases:

1. The letter has an extraordinary level of readability and literacy in the Persian style. Most readers' comments on social networks and websites agreed that "the letter has been written in a way that you don't get tired of reading it a thousand times"! In contrast, translated texts, regardless of how skillfully they have been created, most often use specific language that points to their "translationness" and this often makes them less fluid upon reading.

2. Cultural references such as proper nouns that refer to people and places, along with the naming of a foreign currency, for example, have been used to convince the reader that the letter has originated in a different nation.

\footnotetext{
19 Posted on May 23 ${ }^{\text {rd }}$, 2012. Retrieved on May 13 ${ }^{\text {th }}, 2013$ from http://www.seratnews.ir/fa/news/64872/ بزركترين-دروغ-در -مطبو عات-اير ان-جه-بود

20 The letter was posted on October 1 1st, 2005. Retrieved on May 13 ${ }^{\text {th }}, 2013$ from http:/ /aftabnews.ir/fa/news/16158/نامه-جارلى-جايلين-به-دخترش

21 Posted on May 24 ${ }^{\text {th }}, 2012$. Retrieved on May 13 ${ }^{\text {th, } 2013}$ from http://www.kaleme.com/1391/03/04/klm$\underline{101744 /}$

${ }^{22}$ Posted on August $4^{\text {th }}$, 2013. Retrieved on August $8^{\text {th }} 2013$ from http://www.farsnews.com/newstext.php?nn=13910304000018
} 
3. One of the prerequisites of producing a PT is to thoroughly know the person or the culture under whose veil a pseudo-translator wishes to write. Given his success, it can be surmised that Saba had enough understanding of Chaplin's biography, along with a solid general knowledge of the setting, to make his letter convincing.

4. Because the Rošanfekr Journal has so far remained inaccessible, it has not been possible to verify whether or not Saba was cited as a translator of this text. What is obvious, however, is that ideally either the author or the translator needs to exist in order to create the most convincing PT. As Okhovat (2006) has noted, it is impossible for both an author and a translator to be simultaneously fake.

Chaplin was a famous and popular actor, well known even among the illiterate, lower classes of Iranian society. His childhood poverty and destitution and then his success and fame provided for a fascinating story that touched the hearts of Iranian shopping for a better future of their own. It may be that many of them imagined themselves following Charlie Chaplin's life path, and thus they warmly welcomed advice from him. For these reasons, Charlie Chaplin would be a perfect choice in Saba's mind as an 'author' for his PT.

\section{A Critical Discourse Analysis Of The Letter}

A copy of the Persian text of Chaplin's letter to his daughter Geraldine, along with its English literal translation (done by the present author) can be found in Appendix I and II, respectively. ${ }^{23}$ Additionally, parts of Saba's interview with Serat have also been

\footnotetext{
${ }^{23}$ After an extensive research in various libraries, including the National Library and Archives of Iran, the author failed to find Rošanfekr Magazine in which the letter was published for the first time. Its English translation is unavailable as well. However, it has been published in various books, magazines, and websites afterwards, such as:

Soltāne Sinamāye Komedi: be enžemāme nāmeye mašhoore chaplin be doktaraš [The king of comedies: including Chaplin's famous letter to his daughter] by Ali Zolfaghari (2012) published by Hobab Co.

Charlie Chaplin va nämehāye ou be doktaraš [Charlie Chaplin and his letters to his daughter] by Hadi Kaboodvand (2010) published by Cactus co.
} 
translated (by the author of the present paper) from Persian into English for the reader's benefit (Appendix III). In order to identify traces of Iranian social and cultural ideology that might be found within the text, the English translation is analysed within the historical, literary, and cultural context of the time. This approach has the added benefit of highlighting the strategies Saba used to embed his ideas in the PT. Because the text is not the original but rather an English translation, the focus of analysis includes the content and the terminology of the text but not the syntax. Parts of the letter and their analysis are as follows:

I've heard that in this splendid play, you act as the beautiful daughter of the ruler who was enslaved by the King of Tatars.

The King of Tätärs refers to Mongolian Genghis Khan whose historical savage attack on Iran in the early $13^{\text {th }}$ century A.D. is infamous for devastating many areas in Persia (modern Iran) and massacring many Persians. The sentence is an allusion to Mohammad-Reza Shah, the king of Iran dethroned in 1979, whose dictatorship, in Saba's opinion, was equal to that of Genghis Khan. The reference to a 'beautiful daughter' alludes to Iranian women who, according to Saba, were figuratively enslaved during the Pahlavi regime.

Today, it is your turn to exult in the applause of the audience. Go to the heaven of euphoria but come back to the earth sometimes and see the life of people-the life of those who perform on the stage while their legs shiver because of hunger and poverty. I used to be one of them.

Andišehāye Zibāye Charlie Chaplin: zuendegi nämeh va nāmeye tāriǩi be doktaraš [Beautiful ideas of Charlie Chaplin: his biography and phenomenal letter to his daughter] by Azam Ebrahimi (2010) published by Movafaghiat Co.

Zendegie pedaram Charlie Chaplin: hamräh bā nämeye Chaplin be doktaraš [My father Charlie Chaplin: including Chaplin's letter to his daughter] by Charles Chaplin Jr., translated by Hasan Marandi, Mansoor taraji (2010) Published by Negah Co.

Nāmehāye bārāni: hamrāh ba nāmeye Charlie Chaplin va pāsoḳe dokntarašs [Rainy letters: including Charlie Chaplin's Letter to his daughter and her response] by Mahdi Kakoli (2008) published by Shadiakh Co. 
During the Pahlavi period, the lower classes of Iranian society lived in misery and this created a strong motivation for revolutionists to attempt reforms; thus, the above text refers to both those whose lives were wretched and those, including singers and actors, whom the general public believed lived in luxury.

$>\quad$ However, I'm alive, and the living shouldn't be talked about before their death.

The above text refers to the Iranian practice of only truly acknowledging leading figures, such as artists, writers, and scientists, after their death, regardless of how influential their work might have been while the person was still alive. While this tendency to ignore contributions by living individuals may not be common in other cultures, it is a longstanding practice embedded in Iranian media that would appear to continue today.

$>\quad$ When you think of yourself as superior to others, leave the theatre immediately and go to the suburbs of Paris by taxi. I know the place like the back of my hand. There, you will see actors and actresses who have been performing more beautifully, skillfully, and proudly than you for centuries, but it is far from the dazzling light of Champs-Élysées Theater.

Läleh-Zār, one of the oldest neighborhoods in Tehran, was known as Champs-Élysées before the Islamic Revolution due to its modern structures, famous bars, movie theatres, and restaurants. Many noted singers, actors, and entertainers performed there. Although it was a part of Tehran, most individuals could rarely afford to visit. As an alternative, common people developed their own unique spectacles called $\mathrm{R} u$ Hori, performed at weddings and other festive occasions (Aryanpur, 1973) by unknown actors on a homemade outdoor stage where local people gathered to watch the performance. The themes of these performances included common issues of the day and were often presented in comic forms accompanied by dance and music. Such a play typically consisted of a lovelorn master, a comical black servant, and a beautiful damsel. There was no written script and both the tone and length of the performance depended on the actors' talents and the demands of the occasion (Aryanpur, 1973). 
By skillfully exploiting the famous names of Charlie Chaplin and Geraldine, along with utilizing a well-known street such as the Champs-Élysées, Saba directed his readers' thoughts to the unequal situation existing in Iran at the time. Simultaneously, he invited the noted singers, actors, and entertainers of the day to better understand the lives of the common Iranian by visiting the suburbs and by acknowledging the enormous talent found there.

$>\quad$ But when you want to spend two francs, say to yourself, "The third franc is not mine. It belongs to an unknown poor man who is in the need of one franc tonight."

The idea in this text may refer to an Islamic order called Zakāt and the destitute people who, because of their poverty, are entitled to receive Zakät. Zakät has some specific rules regarding the amount and nature of donations, and Saba's reference in the above passage appears to be of a similar tone.

One night, you may be enchanted by the shine of the most expensive diamond in the world and that night, this diamond is an unstable rope beneath your feet, and undoubtedly you will fall down. When the beautiful face of a noble promiscuous man beguiles you, that day you are a novice acrobat. Novice acrobats always fall down; therefore, don't be attracted by wealth.

In the Islamic faith, As-Sirätis a hair-narrow bridge, sharper than a sword that each person has to cross over on the Yawm ad-Din (i.e. the hereafter) to arrive in paradise. Beneath the bridge lie the fires of Hell, into which sinners fall, but over which righteous people cross into paradise. The rope in the letter alludes to As-Sirät.

I've asked your mother to write a letter for you about this issue. She knows the meaning of love more than me. She is a better person to define "love" which means "mutual understanding."

This passage refers to the Iranian cultural traditions dictating the existence of certain boundaries between fathers and daughters. Within the culture, some subjects such as romantic love were seen as appropriately mediated only by the girl's mother. 
$>\quad$ Nobody and nothing can be found in this world which deserves that a girl unveils her toenail for it. Nudity is the disease of our era.

This passage can be considered the most obvious example of the author's critique of western styles of clothing as they applied to girls and women. In Iran, the majority of people were religious to the extent that many western ways of dress were deemed offensive and immodest. In fact, many Iranians accused Mohammad-Reza Shah of causing moral corruption because of encouraging women to follow western styles.

\section{$>\quad$ Paris, Champs-Élysées, Metro, Franc}

The author has astutely used foreign words to disguise his letter as a translation made from an original, foreign text.

\section{Conclusion}

Charlie Chaplin's letter to his daughter Geraldine is one among many Persian PTs that have not yet been recognized in the literature, since they were not intended to be unveiled from the outset. Why, after more than 30 years, the author chose to publicize the true nature of his story is a question open to various interpretations: 1. Perhaps it was produced as a PT before the Islamic Revolution, and now Saba has no need to conceal its nature as he is not afraid of the Pahlavi regime 2. It could be that the author believes he has lost the 'symbolic capital' he could have achieved with the letter's popularity among people. 3. It is not clear whether it was his regular practice in journalism to fill in the blank spaces by fabricating such stories, and suddenly this one got enormously popular. In any case, he blamed the publisher for all the "trouble" he has had since then:

... I was the chief editor and I didn't want to give up, so I accepted the challenge.

I went to my office and wondered what I should write. Suddenly the picture of Charlie Chaplin and his daughter, published in a magazine on my desk, attracted my attention. In the interim, the publisher was persistent in finalizing the pages as soon as possible. Finally, he didn't print Fantasy at the top of the column and this led to my troubles all these years. 
Whatever the actual reason, the letter serves as an excellent example of the complex nature of texts produced in differing cultures. Certainly, the more deeply we delve into the field of translation studies, the more the notion of "genuineness" appears to lose its meaning. The notion of a translation with a sacred source text is disappearing ${ }^{24}$ in the modern world, and new modes of expressing ideas are being recognized. As a matter of fact, construing translation only from a linguistic perspective is a simplistic approach that doesn't get us very far. By analyzing the linguistic features of this letter, in addition to its historical, political, and literary context, the present study has highlighted the complexity of the process whereby a piece of literature is produced, published, and received in a society.

Acknowledgments: I would like to express my deepest gratitude to Dr. Salah Basalamah, Dr. Marc Charron, and Dr. Brenda J. Bettridge for their invaluable comments on my paper.

${ }^{24}$ The author doesn't say "has disappeared", since people, in many cultures, still believe in the existence of a sacred original text. 


\section{REFERENCES}

Tahir Gürçağlar, Şehnaz. "Scouting the borders of translation: pseudotranslation, concealed translations and authorship in twentieth-century Turkey." Translation Studies 3.2 (2010): 172-187.

Apter, Emily. "Translation with no original: scandals of textual reproduction." Nation, language and ethics of translation. Ed. Sandra Bermann and Michael Wood. Princton \& Oxford: Princeton University Press, 2005. 159-174.

Aryanpur, Manoochehr. A bistory of Persian literature. Tehran: Kayhan Press, 1973.

Basalamah, Salah. "Translational critique of the Arab postcolonial condition." Globalization and the aspects of translation. Ed. Said M Shiyab, et al. Cambridge: Cambridge Scholars Publishing, 2010. 68-77.

Encyclopadia Iranica. 2010. 12 April 2013. <http://www.iranicaonline.org/>.

Lefevere, André Alphons. Translation, rewriting and the manipulation of literary fame. London \& New York: Routledge, 1992.

Milani, Mohsen M. The marking of Iran's Islamic Revolution: from monarchy to Islamic repulic. Second . Colorado \& Oxford: Westview Press, 1994.

Munday, Jeremy. Introducing translation studies: theories and applications. London \& New York: Routledge, 2001.

Okhovat, Ahmad. Mosta'ar Nevisi va Shebhe Tarjomeh. Tehran: Ney Publishing Co., 2006.

Persian Dictionary Debkhoda. n.d. 12 April 2013. <http://loghatnaameh.org>.

Popovič, Anton. Dictionary for the analysis of literary translation. Edmonton: University of Alberta, 1976. 
Rastegar, Kamran. Literary modernity between the Middle East and Europe: textual transactions in nineteenth-century Arabic, English, and Persian literarture. London \& New York: Routledge, 2007.

Rizzi, Andrea. "When a text is both a pseudotranslation and a translation: the enlightening case of Matteo Maria Boiardo (1441-1494)." Beyond descriptive translation studies: investigations in homage to Gideon Toury. Ed. Anthony Pym, Miriam Shlesinger and Daniel Simeoni. Amsterdam \&Philadelphia: John Benjamins, 2008. 153-162.

Robinson, Douglas. "Pseudotranslation." Routledge encyclopedia of translation studies. Ed. Mona Baker. London \& New York: Routledge, 1998. 183-185.

Roshan, Ali-Reza. Negabi be momayezi az dore Qajar ta Enqelab. 09 Sep 2011. 19042013.

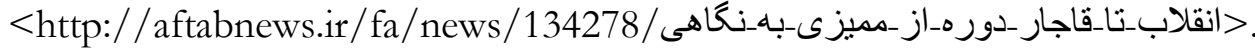

Snell-Hornby, Mary. The turns of translation studies. Amsterdam \& Philadelphia: John Benjamins, 2006.

Toury, Gideon. "Enhancing cultural changes by means of fictitious translations." Translation and cultural change. Ed. Eva Hung. Amsterdam \& Philadelphia: John Benjamins, 2005. 3-18.

Tymoczko, Maria. "Ideology and the position of the translator." Apropos ideology. translation Studies on Ideology - ideologies in translation studies. Ed. M Calzada Pérez . Manchester: St. Jerome, 2003. 182-201. 


\section{Appendix I: Charlie Chaplin's Letter To His Daughter Geraldine ${ }^{25}$ (In Persian)}

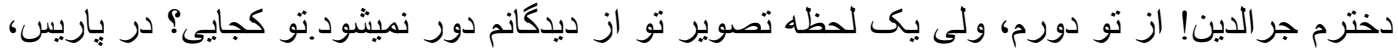

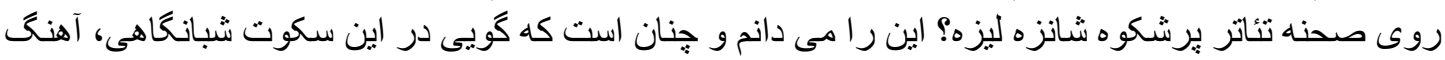

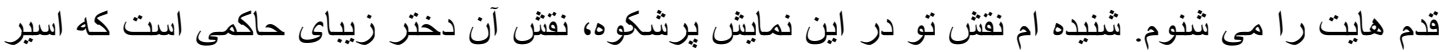

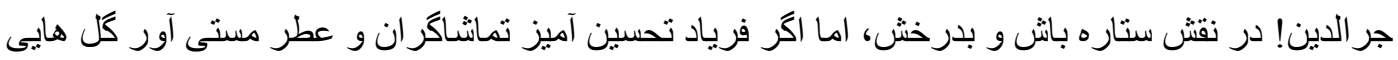

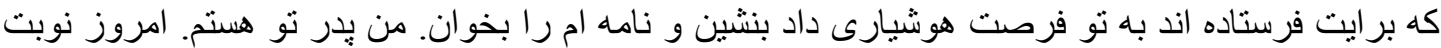

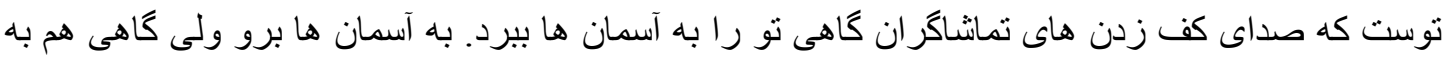

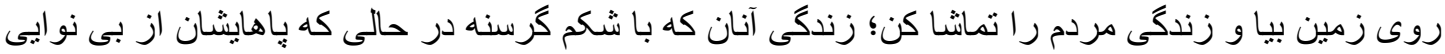

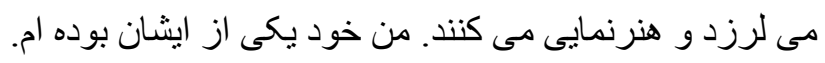

جر الدين دخترم! تو مرا درست نمى شناسى در آن شب هاى بس دور با تو قصه ها بسيار كفتم اما غصها

$$
\text { هاى خود را هركز نكفتم آن هم داستانى شنيدنى است. }
$$

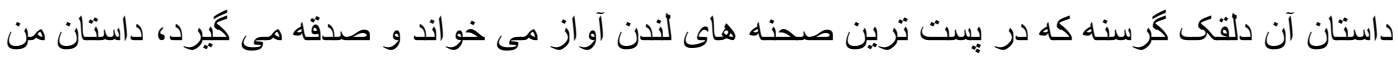

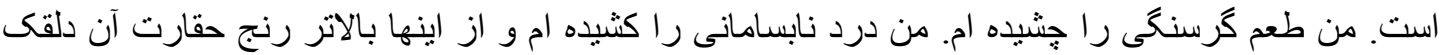

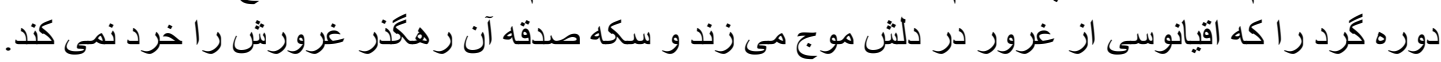

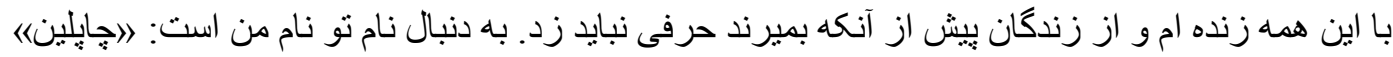

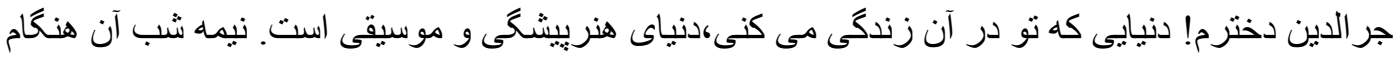

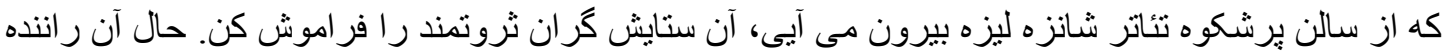

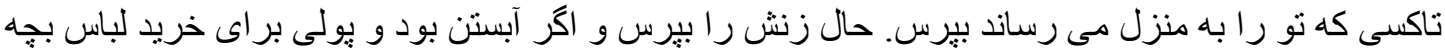

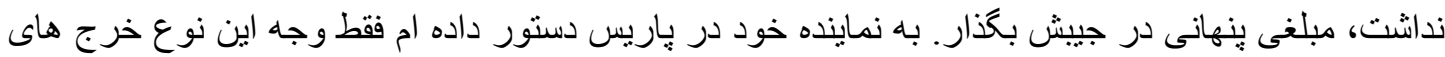

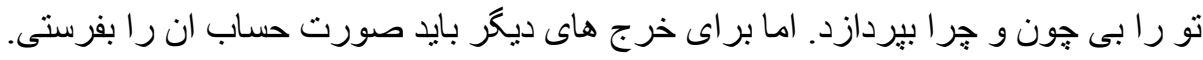

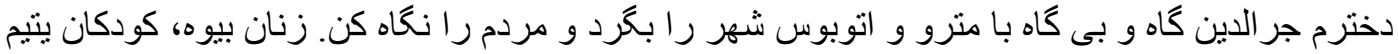

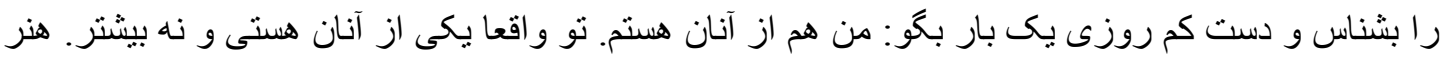

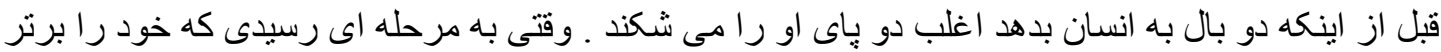

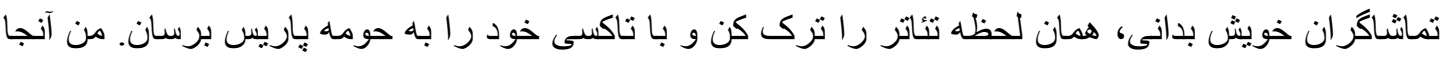

25 The Persian letter has been extracted on May 13 $3^{\text {th }} 2013$ from http://www.kaleme.com/1391/03/04/klm-101744/ 


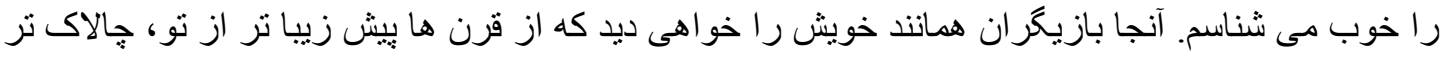

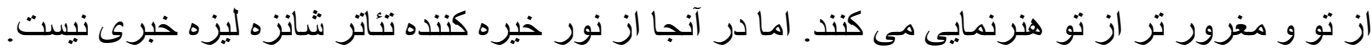

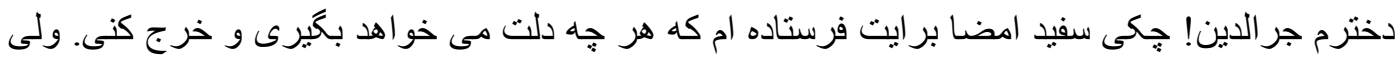

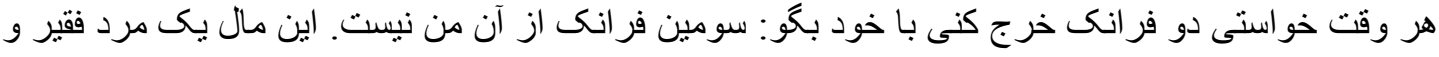

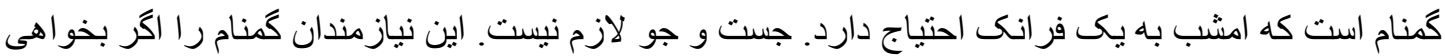

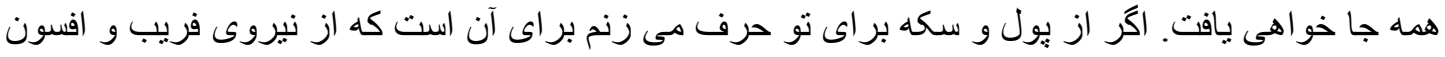

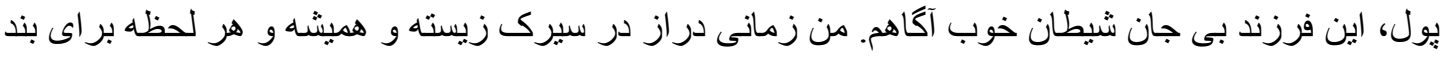

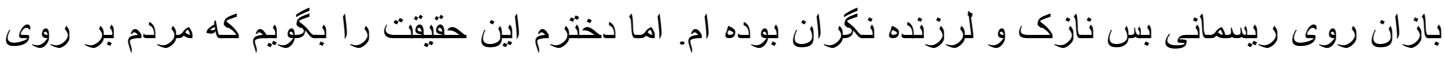

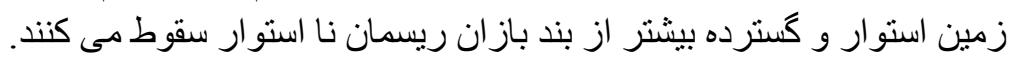

دخترم جر الدين! بدرت با تو حرف مى زند. شايد شبى درخشش كر انبهاترين الماس اين جهان تو را فريب

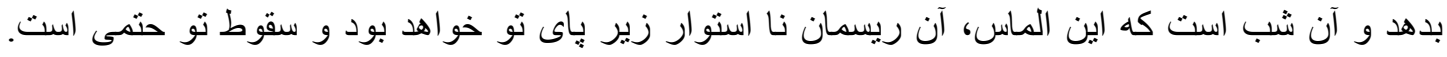

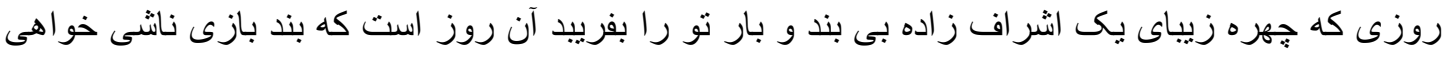

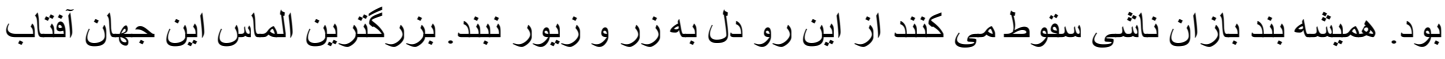

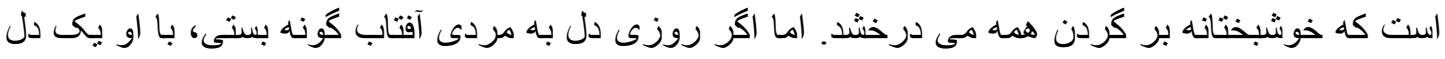

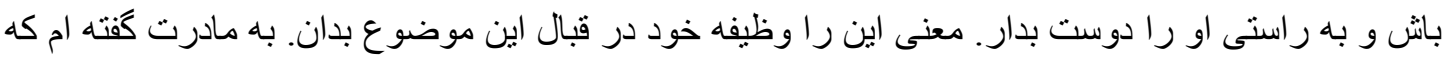

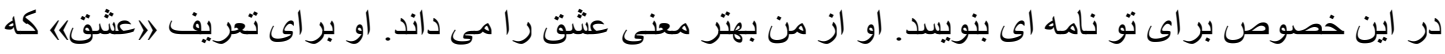

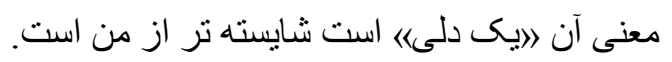

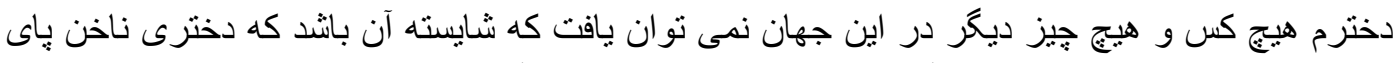

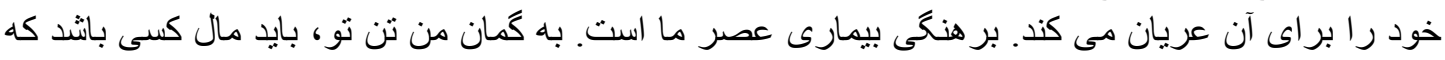

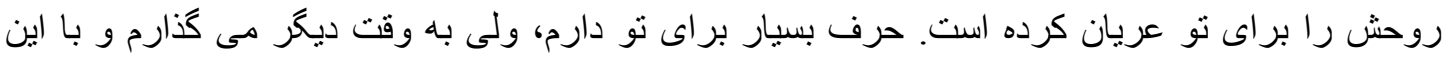

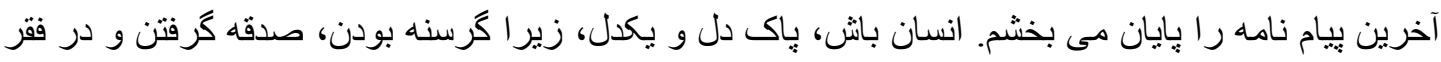

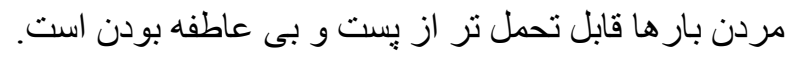




\section{Appendix II: Charlie Chaplin's Letter To His Daughter Geraldine (My Translation)}

Dear Geraldine! Although I'm far away from you, your face is always is in front of me. Where are you? In Paris, in the glorious Champs-Élysées Theatre? I know that, and it seems tonight I can hear the sound of your steps in the darkness. I've heard that in this splendid play, you act as the beautiful daughter of the ruler who was enslaved by the King of Tatars.

Geraldine! Act as a star and shine! But if you get the opportunity among the acclamation of the audience and the fragrant flowers they have sent you, sit and read my letter. I'm your father. Today, it is your turn to exult in the applause of the audience. Go to the heaven of euphoria but come back to the earth sometime and see the life of people - the life of those who perform on the stage while their legs shiver because of hunger and poverty. I used to be one of them.

Dear Geraldine! You don't know me completely. For many nights, I've told you many stories but not my griefs which are also interesting stories.

My story is that of a hungry clown who sang and got alms on the most abject stages of London. I've experienced poverty. I felt the pain of misery, and above all, I know the humiliating agony of that wandering clown whose pride is not hurt by the coin of a pedestrian. However, I'm alive, and the living shouldn't be talked about before their death. You have my last name "Chaplin."

Dear Geraldine! You live in the world of acting and music. When you come out of the glorious Champs-Élysées Theater at midnight, forget those wealthy admirers! Ask your taxi driver about his life and his wife. If she is pregnant, and her husband doesn't have money to buy clothes for his child, put some money in his pocket stealthily.

Dear Geraldine! Occasionally, roam around the city by bus and metro and look at people! Find widows and orphans and at least once a day, say to yourself, "I'm one of them." You are really one of them, period. Art breaks the legs of people before giving wings to them. When you think of yourself as superior to others, leave the theatre immediately and go to the suburbs of Paris by taxi. I know the place like the back of my 
hand. There, you will see actors and actresses who have been performing more beautifully, skillfully, and proudly than you for centuries, but it is far from the dazzling light of Champs-Élysées Theater.

Dear Geraldine! I've sent you a signed blank cheque to buy whatever you desire and spend as much as you want. But when you want to spend two francs say to yourself, "The third franc is not mine. It belongs to an unknown poor man who is in the need of one franc tonight." No need to search. You can find these destitute people everywhere. I'm talking to you about money because I'm quite aware of the temptation and lure of money, the inanimate child of the Devil.

Dear Geraldine! Your father is talking to you. One night you may be enchanted by the shine of the most expensive diamond of the world and that night, this diamond is an unstable rope beneath your feet, and undoubtedly you will fall down. When the beautiful face of a noble promiscuous man beguiles you, that day you are a novice acrobat. Novice acrobats always fall down; therefore, don't be attracted by wealth. The biggest diamond in this world is the sun which fortunately shines at everyone's neck. But if you fall in love with a sun-like man, be honest with him and truly love him! Be responsible about it. I've asked your mother to write a letter to you about this issue. She knows the meaning of love more than me. She is a better person to define "love" which means "mutual understanding."

Geraldine! Nobody and nothing can be found in this world which deserves that a girl unveils her toenail for it. Nudity is the disease of our era. In my opinion, your body belongs to a man who has unveiled his soul for you. I have much to say to you, but I will postpone it for later and end my letter with my last message: be humane, honest, and understanding, because getting alms and dying in poverty are more tolerable than being vicious and heartless.

Your father, Charlie Chaplin 


\section{Appendix III: Some Parts of The SeratNews Interview On May 23 ${ }^{\text {rd }}, 2013$ With Farajollah Saba (My Translation)}

The story happened at the Rošanfekr Magazine. Farajollah Saba says: "More than 30 years ago, we decided to have a column called Fantasy imitated from westerners. We wanted to test our ability. Every week, we published a fantasy letter in the column. The title "Fantasy" at the top of the column clarified everything. After a year, I noticed that the content of the column had gotten repetitive. One day, in the afternoon, I asked my colleagues, "Why has the content got repetitive?"

They said: "If you think you can write better, go ahead!" Well, I was the chief editor and I didn't want to give up, so I accepted the challenge. I went to my office and wondered what I should write. Suddenly the picture of Charlie Chaplin and his daughter, published in a magazine on my desk, attracted my attention. In the interim, the publisher was persistent in finalizing the pages as soon as possible. Finally, he didn't print Fantasy at the top of the column and this led to my troubles all these years."

After publishing this letter, the trouble began: "It was recorded on tapes, declaimed on different occasions, recited on the radio and television frequently, and sold in front of the Tehran University. Nobody paid attention to me insisting that it was not Charlie Chaplin's. The worst thing is that it was translated into Turkish, German, and English. Even in some assemblies I attended, this letter was recited, and when I told them it had been born out of my imagination, they laughed at me and said "What are you talking about? We've seen its English version!" 